\title{
Meta
}

Journal des traducteurs

Translators' Journal

\section{Wolf, Michaela and FuKARI, AlEXANDRA, eds (2007): \\ Constructing a Sociology of Translation. Amsterdam/Philadelphia: John Benjamins, 222 p.}

\section{Juan Zarandona}

Volume 56, numéro 1, mars 2011

URI : https://id.erudit.org/iderudit/1003519ar

DOI : https://doi.org/10.7202/1003519ar

Aller au sommaire du numéro

Éditeur(s)

Les Presses de l’Université de Montréal

ISSN

0026-0452 (imprimé)

1492-1421 (numérique)

Découvrir la revue

Citer ce compte rendu

Zarandona, J. (2011). Compte rendu de [WOLF, MICHAELA and FUKARI, ALEXANDRA, eds (2007): Constructing a Sociology of Translation. Amsterdam/Philadelphia: John Benjamins, 222 p.] Meta, 56(1), 216-218.

https://doi.org/10.7202/1003519ar d'utilisation que vous pouvez consulter en ligne.

https://apropos.erudit.org/fr/usagers/politique-dutilisation/ 


\section{DOCUMENTATION}

\section{Comptes rendus}

Wolf, Michaela and Fukari, Alexandra, eds (2007): Constructing a Sociology of Translation. Amsterdam/Philadelphia: John Benjamins, $222 \mathrm{p}$.

The "Table of contents" of a book, specially a sound and well-organized academic research manual, has sometimes been compared to a professional or company "business card." It gives a basic first impression, overloaded with the phatic function of language, i.e., the one that facilitates or hinders effective communication - an impression that may be significantly influence many future developments. As far as Constructing a Sociology of Translation is concerned, the word 'developments' as used here can mean 'sharing the results of one's research,' 'spread of specialized knowledge,' and 'consolidation, or better construction, of a subdiscipline' (Sociology of Translation).

An Introduction by one of the editors, Michaela Wolf, precedes the table of contents which is perfectly organized into four sections by subject matter or research challengers: Part I. The debate on the translator's position in an emerging sociology of translation; Part II. Bourdieu's influence in conceptualising a sociology of translation; Part III. Mapping the field: Issues of method and translation practice; and Part IV. Constructing a sociology of translation studies: Overview and perspectives. Each section consists of two or three chapters, giving prospective readers an impression of order, balance, regularity, coherence-cohesion, and organisation. Indeed, it looks like a very welcoming business card.

But 'indexes' are not only designed to be phatic or a communication-friendly tool. They are also meaningful; they must make room for the referential function of language; they must summarize and advance the main concepts, ideas, theories, empirical data, research findings and prospects under discussion in the coming pages and chapters. This hybrid title combining the spheres of influence of Sociology and Translation opens with the word 'constructing,' an absolutely purposeful choice. Analyzing the section and chapter titles reveals an underlying semantic network of closely related words and expressions, both in English and French. In other words, there is a non-stop parade of reiterative linguistic items such as 'emerging,' 're-lecture, 'outline for,' 'future prospects,' 'negotiating borderlines,' 'mapping the field,' 'bridge concepts,' 'overview and perspectives,' or the absolutely self-explanatory 'Y a-t-il place pour une socio-traductologie?' by Yves Gambier, etc., which introduces the need for a future construction and consolidation of a Sociology of Translation, the main purpose and driving force of this manual.

But just as a company is much more than its business card, a book also relies on many other factors that go beyond its table of contents. A business demands valuable assets such as a highly qualified workforce, competitive saleable products, and a well-defined target market. Equally, a scholarly work such as Constructing a Sociology of Translation, published by a high prestige company such as John Benjamins for inclusion in its renowned Benjamins Translation Library (BTL), requires a proven team of researchers, a title that truly represents a breakthrough contribution, and a set of proposals responding to the intellectual demands of a sufficient number of specialists in their field of knowledge.

Constructing a Sociology of Translation, on the one hand, lines up a total of eleven contributors, three of them working in Canadian Universities: Hélène Buzelin, Jean-Marc Gouanvic, and the late Daniel Simeoni (1949-2007). The rest are associated with and developed their professional careers in six European countries, at some of their most prestigious universities and research centres, regardless of their origin and educational background: Mirella Agorni, Italy; Andrew Chesterman, Finland; Yves Gambier, Finland; Johan Heilbron, France and The Netherlands; Theo Hermans, UK; Erich Prunč, Austria; Gisèle Sapiro, France; and Michaela Wolf, Austria. If one were to combine the most relevant items in their collective CVs towards constructing a Sociology of Translation, the research team profile would list the following outstanding qualities: proven specialization in Translation Theory, History of Translation, Literary Translation, Translation Pedagogy, sound background in Sociology, Linguistics (Sociolinguistics) and Literary Studies (Sociology of Literature), multilingual communication, business schools, long experience in training translators and teachers of translation, publication of many books and research articles, CETRA, EST, TTR, ESSE, CNRS, etc. The expertise of the aforementioned contributors to tackle the challenge of constructing a Sociology of Translation is beyond doubt. 
On the other hand, this Benjamins Translation Library title presents a wide range of proposals, all dealing in one way or another with the explicit themes defined by the editor, Michaela Wolf, in the opening paragraph of her "Introduction," sub-entitled "The emergence of a sociology of translation":

Any translation, as both an enactment and a product, is necessarily embedded within social contexts. On the other hand, the act of translating, in all its various stages, is undeniably carried out by individuals who belong to a social system; on the other, the translation phenomenon is inevitably implicated in social institutions, which greatly determine the selection, production and distribution of translation and, as a result, the strategies adopted in the translation itself (2007: 1).

Part I, its general heading quoted above, deals with those individuals, the translators, who belong to a social system, in the first chapter by Erich Prunč entitled: "Priests, Princes and Pariahs. Constructing the Professional Field of Translation," which is as a succinct cultural and social history of the different images of the translator, no matter how misleading they are or have been, from genius to anonymous individual. And, what is probably the most outstanding contribution of this chapter, the role played by translation researchers and scholars in creating and perpetuating these conceptions. The passages devoted to Bible translators are particularly interesting. Readers are then offered Theo Herman's challenging contribution, "Translation, Irritation and Resonance," in which takes its lead from the ideas of German social theorist Niklas Luhmann's (1927-1998). The most telling concept that emerges from this chapter is the one called 'second-order' observation. Translators engage in this sort of observation when they comment upon other translations through their own translations. One fascinating example is the triangle made up by ancient Aristotle, medieval Averroes (Ibn Rushd) and contemporary Jorge Luis Borges.

Part II begins with Jean-Marc Gouanvic's paper "Objectivation, réflexivité et traduction. Pour une re-lecture bourdieusienne de la traduction." Pierre-Félix Bourdieu (1930-2002), the acclaimed French social theorist and guru of contemporary Sociology, is the protagonist of this second section and of the construction of a sociology of translation. Some of his notions - field, habitus, illusion, symbolic capital - become the driving force of this chapter devoted to an analysis of translation as social practice and to the enlargement and bold re-elaboration of some of the previously held foundations of translation. His examples are taken from US literature translated into French. The second chapter in this section, by Johan Heilbron and Gisèle Sapiro, "Outline for a Sociology of Translation. Current Issues and Future Prospects," also discusses the contribution of the discipline of Sociology to social questions in translation studies, but from the point of view of Bourdieuinspired researchers linking both disciplines. The chapter concludes that to understand translation as a social practice, it is necessary to bypass purely textual approaches and reintegrate into the analysis all the (social) agents that participate in this practice, including political, economic, and cultural power relations. Finally, Michaela Wolf's chapter, entitled "The Location of 'The Translation Field.' Negotiating Borderlines between Pierre Bourdieu and Homi Bhabha," shifts the focus both from Bourdieu, and from Bourdieu's followers, to an alternative, or complementary, theoretical framework which may allow a better analysis in her opinion: the sociologist Homi Bhabha's (1949- ) notion of Third Space. This proposal can no doubt be regarded as a major step forward in the construction of a sociology of translation.

Part III, deals with the mapping of the field and methodology issues, and opens with a contribution entitled: "Locating Systems and Individuals in Translation Studies," by Mirella Agorni. This researcher argues for the adoption of a methodology focused on the local dimension of translation, what she terms 'localism.' This approach enables mediation between systems and individuals, no longer considered as two opposing poles, and gives translation its specific environment. Hélène Buzelin's chapter draws its inspiration from a different source, in the 'Actor-Network Theory' developed by French philosopher, sociologist and anthropologist Bruno Latour (1947- ), a theory which may even help overcome the limits of the polysystem theory. Buzelin's scrutinizes the numerous stages of the translation process, focusing on literary translation in Montreal, her main corpus of study. Finally, this section concludes with the contribution by Andrew Chesterman: "Bridge concepts in translation sociology," which claims there is a strong need to define various bridge concepts linking the multiple approaches available. This view offers some relief to those already entangled in the complex variety of approaches.

Part IV, the last section, concludes the work with two papers providing a sociologically oriented meta-discussion of translation studies. Daniel Simeoni's "Between Sociology and History. Method in Context and in Practice" reflects upon methods in translation studies previously tested in History, Sociology and other social and human sciences. His case study discusses the first Italian translation of William Shakespeare's Julius Caesar by Domenico Valentini, Giulio Cesare (1756), and shows the relevance of micro-contextual analysis for a sociol- 
ogy of translation, an analysis frequently neglected in favour of macro-contextual levels (norms). The last section and book chapter, by Yves Gambier, "Y a-t-il place pour une socio-traductologie?" is explicit in expressing the need to establish and develop 'socio-translation studies,' as he calls this new sub-discipline in the making. In other words, it is a branch that above all must operate around a number of key labels: 'scholars,' 'historiography of the field,' 'institutions and publications shaping and identifying it.'

The challenge has been issued - the book is on sale -, but this pioneering task continues. New proposals, papers, monographs are wanted. Or, as Michaela Wolf states in her enriching "Introduction":

The various thoughts, approaches and elements of theoretical groundwork presented in this introduction are both divergent and competing. However, they all, from varying perspectives and with different methods, aim to foreground the relevance of translation as social practice ... This books aims to show that even if the domain of "translation as a social practice" is still under construction, its outlines are most certainly beginning to come into view (2007: 27, 31).

There is no doubt that Constructing a Sociology of Translation fulfills the major objectives of its editors and contributors. Future researchers will publish new titles on this subject when the discipline is finally 'constructed,' but the impact and vision of this manual will remain. There will be continued gratitute to Michaela Wolf and Alexandra Fukari, its visionary editors, for this monumental achievement.

JUAN ZaRANDONA Universidad de Valladolid, Valladolid, Spain

Bomati, Yves, dir. (2008) : L'administration en bons termes. Paris: Vuibert, $494 \mathrm{p}$.

Quel amoureux de la langue ne s'est jamais perdu en rêveries en feuilletant les citations enchanteresses du Grand Robert (ou, à défaut, du Petit)?

Et pourtant, quel traducteur n'est pas resté perplexe devant une définition ou une citation du Petit Robert qui, certes, le charment, mais n'ont rien pour répondre à ses besoins immédiats, compte tenu de la nature précise des textes qui lui sont confiés?

C'est ainsi que le traducteur se prend parfois à rêver d'un dictionnaire qui, tout en présentant les qualités du Robert, lui parlerait non pas principalement des trésors de la littérature française, mais des ressources du français administratif, celui avec lequel il joue - n'osons pas dire se débat - dans son travail quotidien.
C'est l'outil qu'on lui annonce sur la couverture de L'Administration en bons termes - 1000 mots clés pour comprendre et utiliser le langage administratif. Le traducteur n'aura pas manqué de remarquer le choix des mots comprendre (donc, il y aura des définitions) et utiliser (donc, il y aura des exemples et, si on est chanceux, des cooccurrents).

Or, en feuilletant l'ouvrage, il se rendra compte que celui-ci ne s'adresse pas vraiment au langagier. On le dit d'ailleurs en avant-propos: il s'adresse "aux étudiants et aux fonctionnaires qui passent les concours administratifs, aux fonctionnaires [et] aux citoyens qui désirent dialoguer avec l'administration» (p. 8). La brochette des auteurs est également significative: dix signataires jouissant d'une longue expérience de l'administration sous toutes ses facettes, mais pas de linguiste, et encore moins de traducteur.

Deuxième déception du traducteur québécois - et il s'y sera attendu: l'ouvrage est francofrançais. Partant, une part substantielle de ses articles ne revêtira qu'un intérêt marginal pour lui. Pensons à des termes - nombreux - du genre Fonds régional d'art contemporain (FRAC), Objectif national d'évolution des dépenses d'assurance maladie (ONDAM) ou Direction régionale des affaires culturelles (DRAC). Pour ce qui est des termes à portée plus générale, le traducteur n'apprendra pas nécessairement grand-chose en consultant des articles comme formation permanente, taux d'imposition ou dossier médical. Même dans un article comme État, terme qui n'est pas sans intérêt pour le traducteur administratif qui jongle entre les différentes traductions de government (gouvernement, administration, pouvoirs publics, autorités, ou État?), il n'y trouvera pas une réflexion plus poussée que ce que lui offriront ses documents de référence habituels.

Cela dit, l'ouvrage est loin d'être dénué d'intérêt pour le traducteur curieux de faits de langue idiomatique. En effet, s'il y a un peuple qui s'y connaît en langage administratif, c'est bien les Français. Ainsi, si le traducteur trouvera dans le dictionnaire peu d'articles qui sauront lui être utiles sur le plan strictement du contenu, et si par ailleurs l'ouvrage lui apporte peu ou prou de ces observations linguistiques dont il est friand (distinctions entre quasi-synonymes, cooccurrents), ce n'est pas sans se délecter que le traducteur averti, en examinant les définitions ingénues de ces fonctionnaires, trouvera toutes sortes de tournures propres à l'aider à sortir de ses ornières. Prenons au hasard l'article formalité: «Opération que doivent obligatoirement accomplir l'administration ou l'administré pour assurer la validité de leurs actes ou de leurs demandes. S'agissant de l'autorité administrative, l'inobservation de certaines formalités dites "substantielles" peut 